\title{
Effect of Different Cultural Conditions for Phytase Production by Aspergillus niger in Submerged Fermentation
}

\author{
Zhanara Suleimenova1, Nurlan Akhmetsadykov'1, Aigul Kalieva², Kairat Mustafin³, \\ Zhazira Saduyeva ${ }^{1}$ \\ ${ }^{1}$ LLP “Antigen”, Almaty, Kazakhstan \\ ${ }^{2}$ Aktobe Regional State University named after K. Zhubanov, Aktobe, Kazakhstan \\ ${ }^{3}$ Almaty University of Power Engineering \& Telecommunications, Almaty, Kazakhstan \\ Email: gnj40@inbox.ru
}

Received 5 April 2016; accepted 5 June 2016; published 8 June 2016

Copyright (C) 2016 by authors and Scientific Research Publishing Inc.

This work is licensed under the Creative Commons Attribution International License (CC BY). http://creativecommons.org/licenses/by/4.0/

c) (i) Open Access

\begin{abstract}
In agriculture, phytase is one of the most important monogastric animal sources of nutrient components because it effectively catalyzes the release of phosphate from phytate and phosphorylated compounds. In present work, Aspergillus niger strain (own collection) was used. Various physical and chemical factors have been known to affect the growth and the production of phytase. The effect of carbon and nitrogen sources, temperature and $\mathrm{pH}$ for extra cellular phytase production was investigated. Maximal phytase activity of Aspergillus niger was detected in media with $1.0 \%$ sucrose as a carbon source. Among the inorganic and organic nitrogen sources, ammonium nitrate in concentration of $0.5 \%$ was found to be a favorable nitrogen source for phytase production in $A s$ pergillus niger. Optimum temperature and $\mathrm{pH}$ for phytase production by Aspergillus niger were $30^{\circ} \mathrm{C}$ and 5.5.
\end{abstract}

\section{Keywords}

Phytase, Aspergillus niger, Submerged Cultivation, Temperature, $\mathrm{PH}$

\section{Introduction}

Parts of the major components of poultry fodder are wheat, soybean meal, corn, which serve as an indispensable source of protein, carbohydrates, calcium and phosphorus. However, those substances are contained in fodder in the form of complex indigestible conglomerates bound by complex organic compounds-phytates and cannot be 
digested by birds. The bioavailability of phytate phosphorus can be increased by supplementation of the diet with the phytase enzyme. Recently, phytases have been of interest for biotechnological applications, as environment friendly feed additives in feed manufacturing industry. Due to the inability of poultry to produce own phytase the availability of phosphorus, calcium, protein and other nutrients is limited. Enrichment of the diet by phytase increases availability of phytate protein, phosphorus, calcium, zinc and copper, improves digestibility and stimulates weight gain [1]-[3].

Phytases are found naturally in plants and microorganisms. Despite the fact that among microorganisms that produce phytase there are bacteria, fungi, yeast and actinomycetes in the recent period micromycets got wide application, particularly Aspergillus fungi because of high productivity [4]. However, great drawback of industrial fungal strains is their low activity, despite the fact that the essential requirement to enzymes is their high activity. The production of phytase enzymes have been affected by a variety of physicochemical factors, such as the composition of the growth medium, the type of strain, cell growth, methods of cultivation, inoculum concentration, time of incubation, $\mathrm{pH}$, temperature, salinity, carbon, nitrogen and mineral sources [5]-[7]. Present investigation involves studies on the effect of carbon and nitrogen sources, temperature and $\mathrm{pH}$ on the production of phytase enzyme by Aspergillus niger in submerged fermentation.

\section{Materials and Methods}

\subsection{Phytase Production in Submerged Fermentation}

Submerged fermentation was carried out using the following cultivation medium: $0.5 \%\left(\mathrm{NH}_{4}\right)_{2} \mathrm{SO}_{4}, 0.05 \% \mathrm{KCl}$, $0.01 \% \mathrm{MgSO}_{4} \cdot 7 \mathrm{H}_{2} \mathrm{O}, 0.01 \% \mathrm{NaCl}, 0.01 \% \mathrm{CaCl}_{2}, 0.001 \% \mathrm{FeSO}_{4}, 0.001 \% \mathrm{MnSO}_{4}, 1.5 \%$ sucrose, $\mathrm{pH}$ 6.5. For inoculum preparation, $25 \mathrm{ml}$ of sterile distilled water was added to the 5-day-old culture grown on potato dextrose agar plates and scraped aseptically with inoculating loop. This suspension with spore concentration of 1.3 $\times 10^{7}$ cells $/ \mathrm{ml}$, was used as inoculum for the cultivation. Aspergillus niger isolate was cultivated for $72 \mathrm{~h}$ at $30^{\circ} \mathrm{C}$ on cultivation medium.

\subsection{Phytase Assay}

Phytase enzyme was determined by spectrophotometric method [8]. A. niger isolate was cultivated for $72 \mathrm{~h}$ at $30^{\circ} \mathrm{C}$ on cultivation medium.

\subsection{Effect of Carbon and Nitrogen Sources.}

Different pure carbon sources (e.g. glucose, sucrose, lactose, maltose, fructose and xylose) with concentration of $1.5 \%$ were added to basal medium replacing sucrose (control) to analyze their effect on phytase production. Enzyme production was optimized by using different organic and inorganic nitrogen sources such as ammonium sulfate, ammonium phosphate, ammonium nitrate, potassium nitrate, peptone and yeast extract with concentration of $0.5 \%$ incorporated in basal medium replacing ammonium sulfate (control).

\subsection{Effect of Temperature}

The sterile cultivation medium $(100 \mathrm{~mL})$ was prepared in different Erlenmeyer flask and inoculated with 2\% inoculum. Each flask was incubated at different temperatures from $10^{\circ} \mathrm{C}$ to $50^{\circ} \mathrm{C}$ for $72 \mathrm{~h}$ on a shaker (220 rpm). The enzyme activity of supernatant was estimated.

\subsection{Effect of $\mathrm{pH}$}

The sterile production medium $(100 \mathrm{~mL})$ was adjusted to different $\mathrm{pH}$ from 2.5 to 9.5 using $0.1 \mathrm{~N} \mathrm{NaOH}$ and $0.1 \mathrm{~N} \mathrm{HCl}$. Each Erlenmeyer flask was inoculated with $2 \%$ fungal inoculum. The flasks were incubated at $30^{\circ} \mathrm{C}$ for $72 \mathrm{~h}$ on a shaker $(220 \mathrm{rpm})$. The enzyme activity of supernatant was estimated.

\section{Results and Discussion}

\subsection{Effect of Different Carbon Sources on Phytase Production by Aspergillus niger}

The results indicated that among the various (fructose, maltose, glucose, xylose, lactose and sucrose) carbon 
sources used for phytase production, sucrose is a suitable carbon source for maximal phytase activity of 2.1 $\mathrm{U} / \mathrm{ml}$ (Figure 1). All other monosaccharides and disaccharides used had less effect on phytase production (enzymatic activity ranged from 0.8 to $1.6 \mathrm{U} / \mathrm{ml}$ ). This indicates that sucrose is the most efficient source for phytase production by A. niger.

The effect of different concentration of sucrose on phytase production was studied using sucrose in the range of $0.25 \%$ to $2 \%$ (Figure 2). Sucrose at $1.0 \%$ concentration was found to support maximal phytase activity (2.6 $\mathrm{U} / \mathrm{ml})$.

\subsection{Effect of Different Nitrogen Sources on Phytase Production by Aspergillus niger}

The result obtained through the studies on the effect of inorganic and organic nitrogen sources on Aspergillus niger phytase production in submerged fermentation is shown in Figure 3.

Among the various nitrogen sources such as ammonium sulfate, ammonium phosphate, ammonium nitrate, potassium nitrate, yeast extract and peptone used for phytase production, ammonium nitrate supported phytase production in A. niger with enzymatic activity of $2.9 \mathrm{U} / \mathrm{ml}$. All other nitrogen sources used had less effect on phytase production with enzymatic activity ranged from 1.8 to $2.7 \mathrm{U} / \mathrm{ml}$.

The various concentration of ammonium nitrate $(0.25 \%-2.0 \%)$ have been used for the phytase production in submerged fermentation (Figure 4). It was found that $0.5 \%$ ammonium nitrate has given the highest enzymatic activity $(2.9 \mathrm{U} / \mathrm{ml})$.

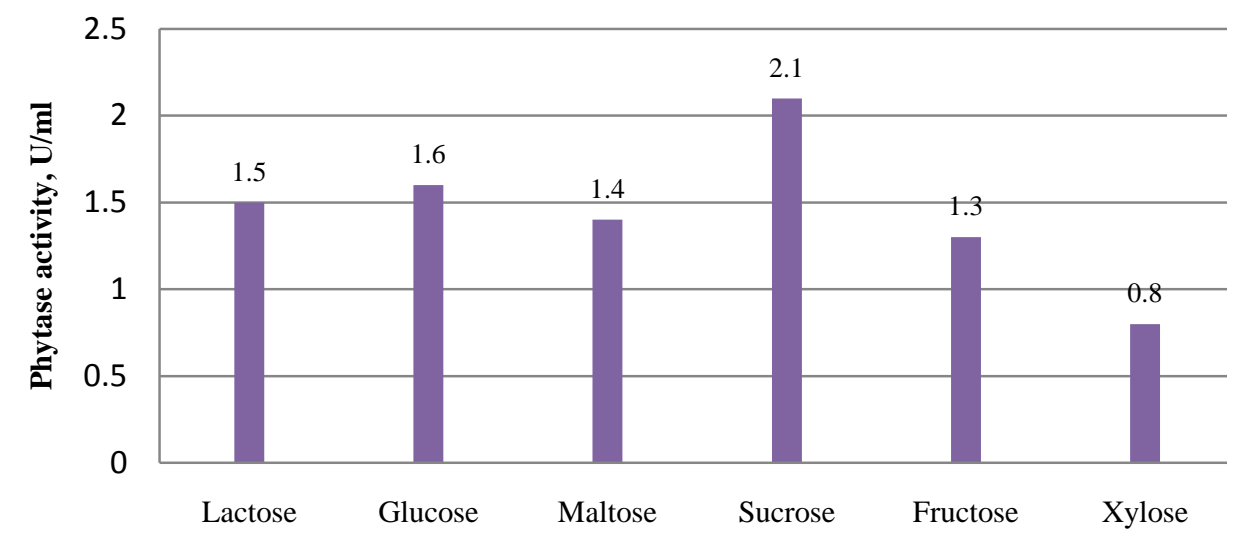

Carbon sources

Figure 1. Effect of carbon sources on phytase production by A. niger in submerged fermentation.

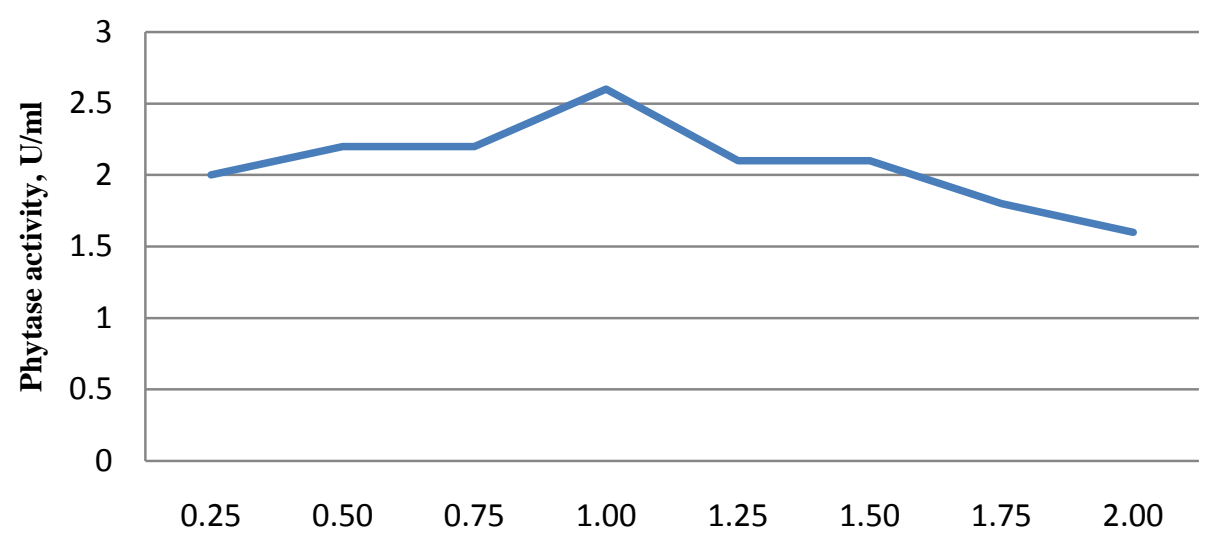

Concentration of sucrose, \%

Figure 2. Effect of different concentrations of sucrose on phytase production by A. niger. 


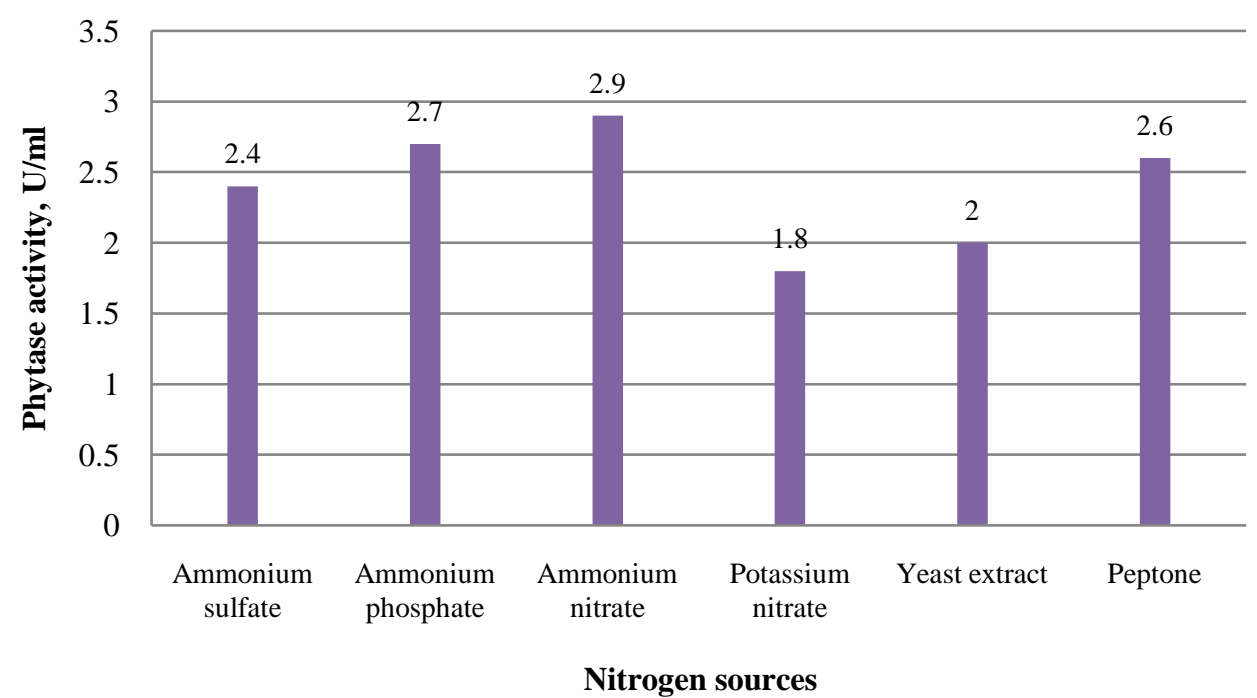

Figure 3. Effect of nitrogen sources on phytase production by A. niger in submerged fermentation.

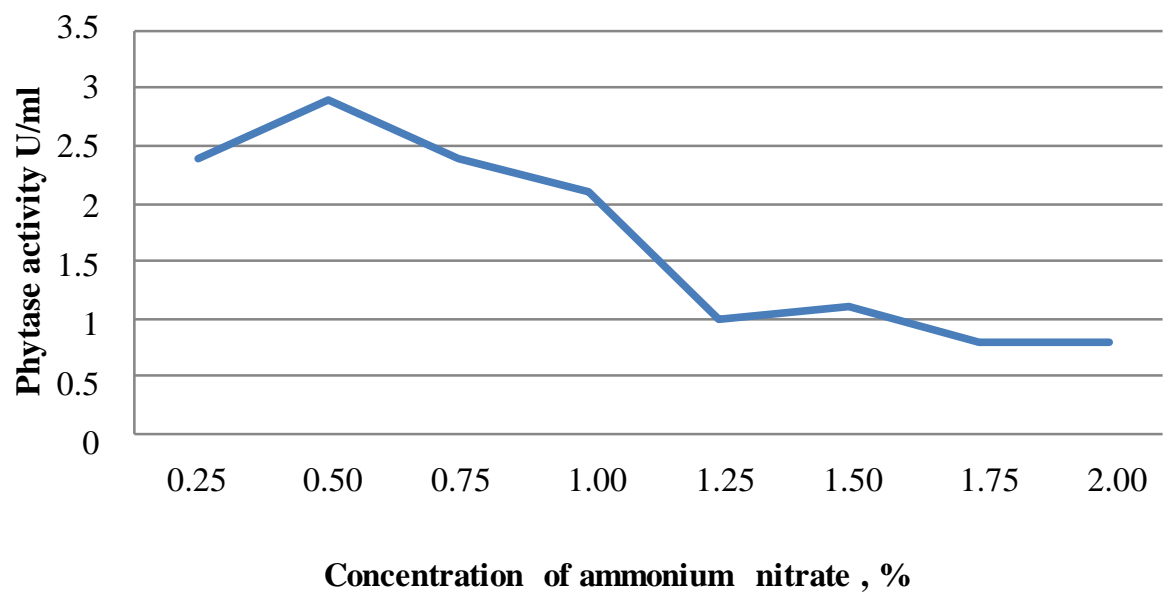

Figure 4. Effect of different concentrations of ammonium nitrate on phytase production by $A$. niger.

\subsection{Effect of Temperature on Phytase Production by Aspergillus niger}

The effect of physical parameters like temperature and $\mathrm{pH}$ on phytase production was investigated. The effect of temperature on phytase activity was determined by incubating the flask at a range of temperature of $10^{\circ} \mathrm{C}-50^{\circ} \mathrm{C}$. The results of the test made at different temperatures value showed that the optimal temperature for phytase production by $A$. niger was between $25^{\circ} \mathrm{C}$ and $35^{\circ} \mathrm{C}$ (Figure 5).

\subsection{Effect of pH on Phytase Production by Aspergillus niger}

To evaluate the effects of $\mathrm{pH}$ on phytase production, the $\mathrm{pH}$ values were adjusted by the addition of $\mathrm{HCl}$ or $\mathrm{NaOH}$ to $2.5,3.5,4.5,5.5,6.5,7.5,8.5$, and 9.5. The optimum $\mathrm{pH}$ for phytase production was found to be 5.5 (Figure 6).

The enzyme activity gradually increased when increasing the $\mathrm{pH}$ up to the optimum. It was also noted that the enzyme activity was stable at $\mathrm{pH}$ range of 4.5 - 7.5.

Thus, among the different nitrogen and carbon sources tested $0.5 \%$ ammonium nitrate and $1.0 \%$ sucrose were found to be good nitrogen and carbon sources for phytase production. Optimum temperature and $\mathrm{pH}$ for phytase production by $A$. niger are $30^{\circ} \mathrm{C}$ and 5.5. 


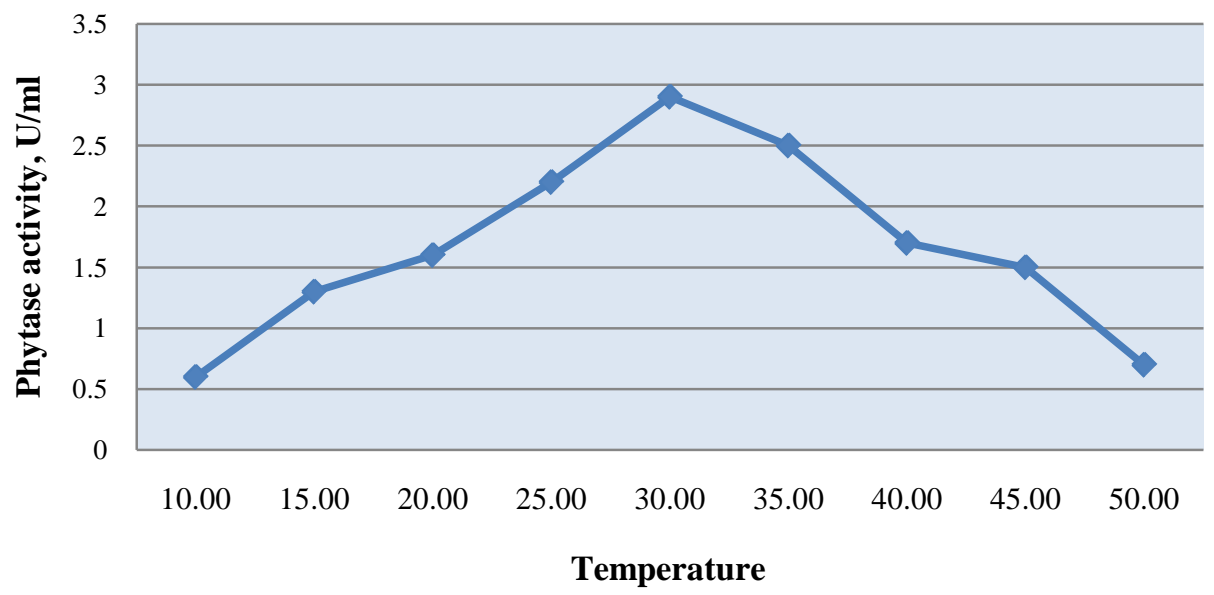

Figure 5. Effect of temperature on phytase production by Aspergillus niger.

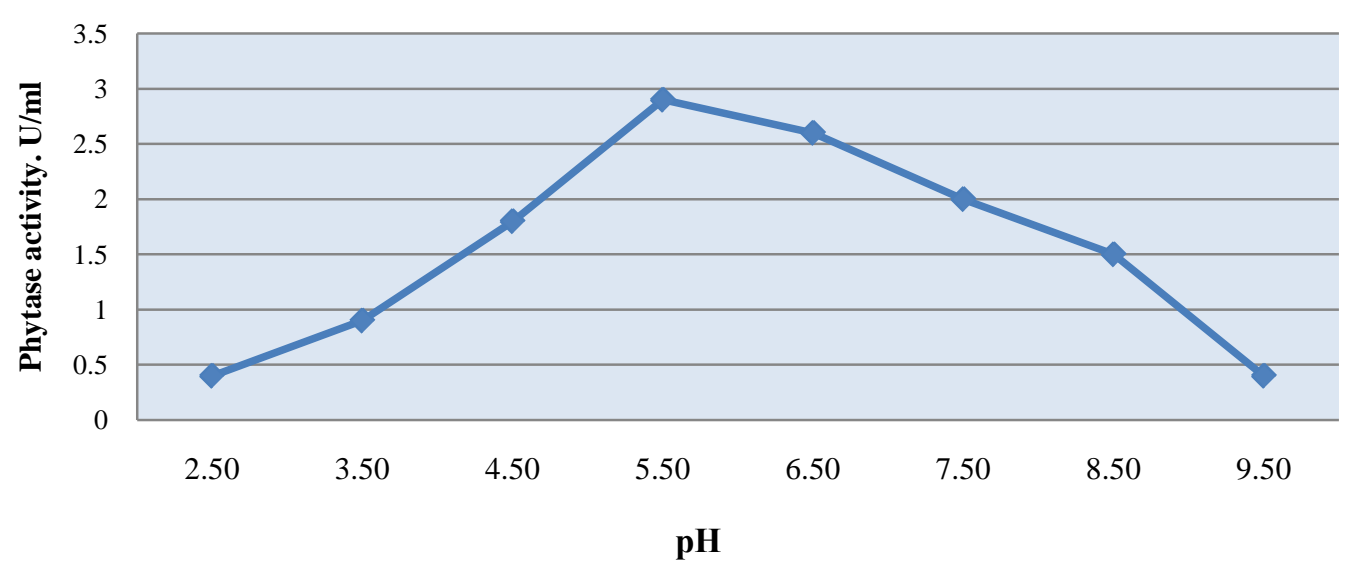

Figure 6. Effect of $\mathrm{pH}$ on phytase production by Aspergillus niger.

\section{Acknowledgements}

This research work was funded by Ministry of Education and Sciences of the Republic of Kazakhstan.

\section{References}

[1] Bahadoran, R., Gheisari, A. and Toghyani, M. (2011) Effects of Supplemental Microbial Phytase Enzyme on Performance and Phytate Phosphorus Digestibility of a Corn-Wheat-Soybean Meal Diet in Broiler Chicks. African Journal of Biotechnology, 10, 6655-6662.

http://www.academicjournals.org/article/article1380885445_Bahadoran\%20et\%20al.pdf

[2] Butani, J.B. and Parnerkar, S. (2015) Role of Microbial Phytase in Broiler Nutrition-A Review. Journal of Livestock Science, 6, 113-118. http://livestockscience.in/wp-content/uploads/phytase-broiler.pdf

[3] Sebastian, S., Touchburni, S.P., Chavez, E.R. and Lague, P.C. (1996) The Effects of Supplemental Microbial Phytase on the Performance and Utilization of Dietary Calcium, Phosphorus, Copper, and Zinc in Broiler Chickens Fed Corn-Soybean Diets. Poultry Science, 75, 729-736.

http://ps.oxfordjournals.org/content/75/6/729.full.pdf+html?sid=d8d2f39a-3ac9-497e-985d-3a67ca66d1cd http://dx.doi.org/10.3382/ps.0750729

[4] Vinetsky, Yu.P., et al. (2011) Increase in Glucoamylase Productivity of Aspergillus awamori Strain by Combination of Radiation Mutagenesis and Plasmid Transformation Methods. Applied Biochemistry and Microbiology, 46, 633-640. http://link.springer.com/article/10.1134\%2FS0003683810060128\#/page-1 http://dx.doi.org/10.1134/S0003683810060128

[5] Gargova, S. and Sariyska, M. (2003) Effect of Culture Conditions on the Biosynthesis of Aspergillus niger Phytase and Acid Phosphatase. Enzyme and Microbial Technology, 32, 231-235. 
http://www.sciencedirect.com/science/article/pii/S0141022902002478 http://dx.doi.org/10.1016/S0141-0229(02)00247-8

[6] Kim, D.-S., Samuel Godber, J. and Kim, H.-R. (1999) Culture Conditions for a New Phytase-Producing Fungus. Biotechnology Letters, 21, 1077-1081. http://link.springer.com/article/10.1023\%2FA\%3A1005696829168

[7] Lambrechts, C., Boze, H., Segueilha, L., Moulin, G. and Galzy, P. (1993) Influence of Culture Conditions on the Biosynthesis of Schwanniomyces castellii Phytase. Biotechnology Letters, 15, 399-404.

http://link.springer.com/article/10.1007\%2FBF00128284 http://dx.doi.org/10.1007/BF00128284

[8] (2012) Method for Determination of Phytase Activity. State Standard of Russian Federation, 51228-51298. http://docs.cntd.ru/document/gost-31487-2012 